\title{
Intellectual Capital in a Bilingual Project between Canada and Peru
}

\author{
Alberto Un Jan1, Mila Kwiatkowska² \\ ${ }^{1}$ Research Development, Universidad Norbert Wiener, Lima, Perú \\ ${ }^{2}$ Computing Science, Thompson Rivers University, Kamloops, Canada \\ Email: emilio.unjan@uwiener.edu.pe,mkwiatkowska@tru.ca
}

How to cite this paper: Un Jan, A. and Kwiatkowska, M. (2017) Intellectual Capital in a Bilingual Project between Canada and Peru. Voice of the Publisher, 3, 43-52. https://doi.org/10.4236/vp.2017.34005

Received: October 29, 2017

Accepted: December 19, 2017

Published: December 22, 2017

Copyright $\odot 2017$ by authors and Scientific Research Publishing Inc. This work is licensed under the Creative Commons Attribution International License (CC BY 4.0).

http://creativecommons.org/licenses/by/4.0/

\begin{abstract}
Thompson Rivers University (TRU), Kamloops, Canada, and Universidad Norbert Wiener (UNW), Lima, Peru, work together in a bilingual project about data mining, managing activities and resources with the help of structures in intellectual capital. Otherwise, without the use of these structures, it would have been almost impossible to have a continuous contact among the persons in the project. The change of authorities at UNW, was not an obstacle to the continuity of the project. Results of this collaboration are achieved in the way of knowledge sharing. In year 1 , a team of professionals in health sciences traveled from Canada to Peru, mainly to give courses. In year 2, an expert in computer science came, together with the professionals in health; this new expert gave conferences in data mining in English language. In year 3 , the expert in computer science gave a main conference and conducted workshops. Year 4 is for joint research and publishing of findings. Three results are: a) conferences and workshops in health sciences and information technology are given in Peru by Canadian experts; b) research papers are produced and published in international congresses and indexed journals; and c) a bilingual experience is given to students in Peru, since conferences and workshops are given in English to Spanish speaking students. A progressive increase in intellectual capital is measured every year during the four-year project. The research question for this paper will be: what is the contribution of intellectual capital to the management of international bilingual projects? The four-year experience, will give the answer to this research question. Outcomes already obtained show that good practices in intellectual capital are contributing to the success of this four-year project.
\end{abstract}

\section{Keywords}

Intellectual Capital, Data Mining, Bilingual Courses 


\section{Introduction}

This research is among efforts at the university level to study the contribution of intellectual capital to educational management. For example, [1] found that intellectual capital of the university became a strategic resource and a core competence in getting a competitive advantage in the global competition. In addition, [2] provided a model for intellectual capital report at Spanish universities. Even more, [3] studied the intellectual capital at the university based on the observation of problems and solutions to bilingual teaching. Moreover, [4] studied a bilingual, peer assisted learning program, for students at an Australian University.

This paper reports the relationship between Thompson Rivers University, TRU, Kamloops, Canada, and Universidad Norbert Wiener, UNW, Lima, Peru, in a four-year project (May 2013 to October 2016). During this time, intellectual capital (IC) has been the key asset to achieve innovation, contributing to the creation of competitive advantage. Intellectual capital was presented for the first time in 1969 by economist Kenneth Galbraith, who described IC as a process to create value and at the same time as an asset [5]. Galbraith presented IC as the difference between value in the market and value recorded in books. The three main components that contribute to intellectual capital are present: human capital, structural capital and relational capital [6].

1) Human capital is present as administrative and academic personnel.

2) Structural capital can be identified in the form of: a) resources, b) organizational structures, c) work instructions, and d) ISO 9001 standards implemented at UNW.

3) Relational capital is namely the satisfaction and loyalty of students.

With the help of structures in intellectual capital, for example work instructions (WI) for a job, activities and resources are being managed in the project; otherwise, it would have been almost impossible to keep a continuous contact among the persons in the project. Results of this collaboration are achieved in the way of knowledge sharing. Results are:

a) Conferences and workshops in health sciences and information technology given in Perú by Canadian experts;

b) Research papers produced and published in international congresses and indexed journals;

c) A bilingual experience given to students in Peru, since conferences and workshops are given in English to Spanish speaking students.

In year 1 [7], a team of professionals in health sciences traveled from Canada to Perú, to give courses, and bring therapeutic equipment for donation. In year 2 , together with the professionals in health, came an expert in computer science; this new expert gave conferences in data mining in English language. In year 3, the expert in computer science conducted workshops using computer laboratories. Year 4 was for joint research and publishing of findings. Dr. Kwiatkowska, Author 2, presented a research article at an international congress; the article is the result of the first three years of work [8]. 
The research question for this paper will be: what is the contribution of intellectual capital to the management of international multilingual projects? The four-year experience, will give the answer to this research question. Outcomes already obtained show that good practices in intellectual capital are contributing to the success of this four-year project.

\section{Importance of the Project for UNW}

Universities in Peru have six functions (Law N³0220, article 7, 2014, [9]): 7.1 Professional formation, 7.2 Research, 7.3 Cultural extension and social projection, 7.4 Continuous education, 7.5 Contribution to human development, 7.6 Other functions assigned by the Peruvian Constitution and the law.

- Social responsibility in universities is the ethical and effective impact management generated by the university on the society, due to the execution of its functions: academic, research and extension services, at different levels and dimensions, in the national development (Law N ${ }^{\circ} 30220$, article 124, 2014 [9]).

- Research refers to finding new knowledge, which finally shows an outcome as published articles.

- Cultural extension is achieved giving courses that do not belong to a career but are a complement for students.

- Social projection is the relationship between university and society: University delivers social services without expecting direct profit; students participate, with the guidance of the university, delivering this social service, thus complementing their professional formation.

This bilingual project contributes to functions 7.2 and 7.3 in the university. Support given to these functions with the tools of intellectual capital shows the importance of identifying such tools in this research. Section 2 describes courses and workshops in data mining, and its contents during 2014 and 2015. Section 3 identifies components of intellectual capital in the project. Finally, conclusions show the contribution of intellectual capital to the bilingual project.

\section{The Presentations in Data Mining}

The central activity in this project was about giving two English versions of the presentations in data mining: May 2014 and May 2015. The two versions were given at UNW by personnel from TRU. In May 2014, the presentation consisted in four different conferences that were given to 120 students:

Data Mining: Decision Tree Induction

Designing a Data Warehouse Database

Advanced SQL: Problem-Based Learning Approach

Applications of data mining in medicine: clinical prediction rules in the assessment of obstructive sleep apnea

In May 2015, the presentation consisted in two workshops and one conference that were given to 169 students: 
Workshop 1: Data mining, general applications (two versions)

Workshop 2: Data mining, applications in engineering and medicine

Conference: data mining, general concepts

Figure 1 shows a sample of the material used for conferences and workshops.

The conferences and workshops were given in English (by personnel from TRU) with simultaneous translation to Spanish (by personnel from UNW). Students were able to listen to both audios. The ability of the students in English was diverse: students with basic knowledge in English, as well as students who could understand and speak English.

Why does UNW need a bilingual project? UNW recognizes the need to give students an education that will be useful when they go to study and work worldwide. Students have studied four semesters of English for Engineering, and now they need to practice their English in a course that is applied to their career.

The contents of the workshops and conferences were prepared by the experts from TRU. These contents were distributed to the participants. The schedules were coordinated with administrative staff from UNW.

\section{Scope of Cooperation}

The scope was satisfactory in terms of number of students participating, and variety of activities offered in years 2, 3 and 4 .

Year 2. Presentation in data mining: three conferences, 120 students.

Year 3. Presentation in data mining: two workshops, one conference, 169 students. Figure 1 shows part of the material distributed.

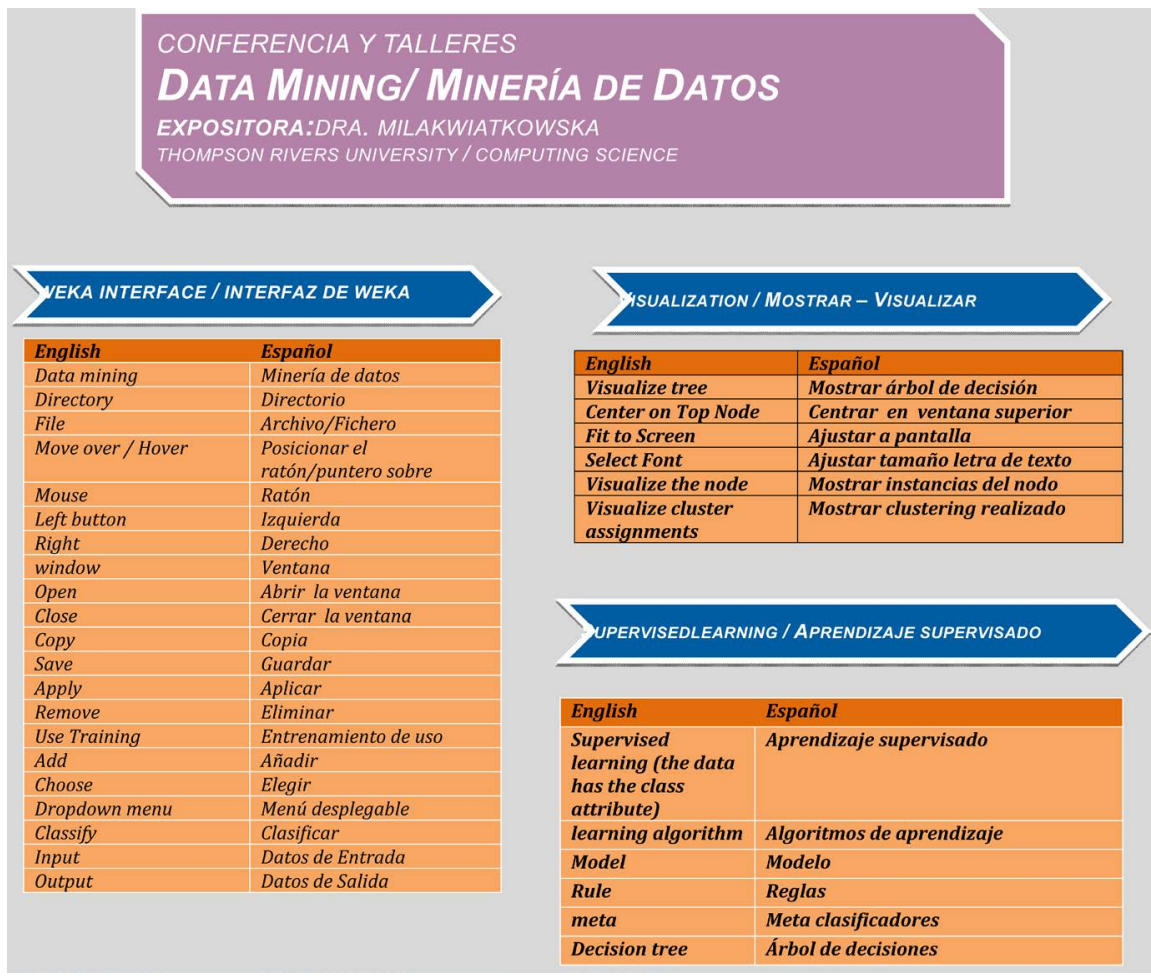

Figure 1. Printed material used for the conferences and workshops. 
Year 4: One research presented at an international conference.

The scope shows that intellectual capital contributes to the success of the project.

\section{The Components of Intellectual Capital}

The three main components that contribute to intellectual capital are ([10] [11] [12]): human capital, structural capital and relational capital.

Human capital describes: individual skills, knowledge and experience. According to [13], human capital is the total amount of staff abilities. For example, establishing competency models and organizational learning practices [14]. Structural capital describes: business systems organizations and information technology, among others. As proposed by [15], structural capital includes organizational processes, procedures, technologies, information resources, intellectual property rights, data base structures, manuals, training materials, databases, organizational charts, process, strategies, and routines. The customer or relational capital relates the business with customers and external business partners [6]. This capital includes clients' portfolio, but also relations with competitors, suppliers, shareholders, governments and public administrations, other stakeholders and their impact on business [13]. The relational capital refers to relational resources emerging from the potential gathered within an organization [16].

Under the combined effect of human capital, structural capital and relationship capital, intellectual capital influences the enterprise performance with organizational learning as an intermediate [17]. It is widely accepted that an organization's capability to innovate is closely tied to its intellectual capital [18].

1) Human capital is present as administrative and academic personnel, both from TRU and UNW.

2) Structural capital can be identified in the form of: a) resources, b) organizational structures, c) work instructions, and d) ISO 9001 standards implemented at UNW.

3) Relational capital is namely the satisfaction and loyalty of students.

4) UNW provides and supports the three main components that contribute to generate intellectual capital: human capital, structural capital and relational capital.

\subsection{Human Capital}

This collaboration project requires personnel both from Canada and Peru. In year 1 of the project, professionals from health sciences came to Peru. The experience of this first year was replicated in year 2, when a professional in engineering joined the team of professionals from health sciences. Experience was shared, in terms of: travel arrangements, accommodation, and coordination of schedules for the visiting lecturers.

Human capital refers to the persons that participate in the project. The Rector 
and the International Relationship Manager at UNW were present during the first three years of the project. The Dean of the Faculty of Engineering at UNW was present during years 2 and 3. In year 4 these three persons did not continue in their positions at UNW. However, the communication between UNW and TRU has continued by email and joint research has been done. As a result of the fourth year, a research paper has been presented at the Global Humanitarian Technology Conference, Seattle, Washington, in October 2016. Although some persons have changed positions during these years, the project continues. Peruvian professors in the project were able to speak English and do simultaneous translation. Also, coordination between the two countries has been made in English thanks to the bilingual skills of the Peruvian professors.

\subsection{Structural Capital}

Structural capital at UNW identifies resources, organizational structures, and work instructions under ISO 9001 standards implemented at UNW.

a) Resources are classrooms and mainly computer laboratories. Figure 2 and Figure 3 show the use of these resources.

b) Organizational structure refers to the persons and their functions. As soon as the tasks in the project are approved, the persons in charge will perform their duties, according to the work instructions.

c) What are work instructions, WI? Work instructions (WI) are a tool from ISO 9001 Standards that specify how the tasks are being performed. WI are written in a manual and stored in a computer system, so they can be transmitted to the personnel, and even if the personnel changes, WI are accomplished. WI

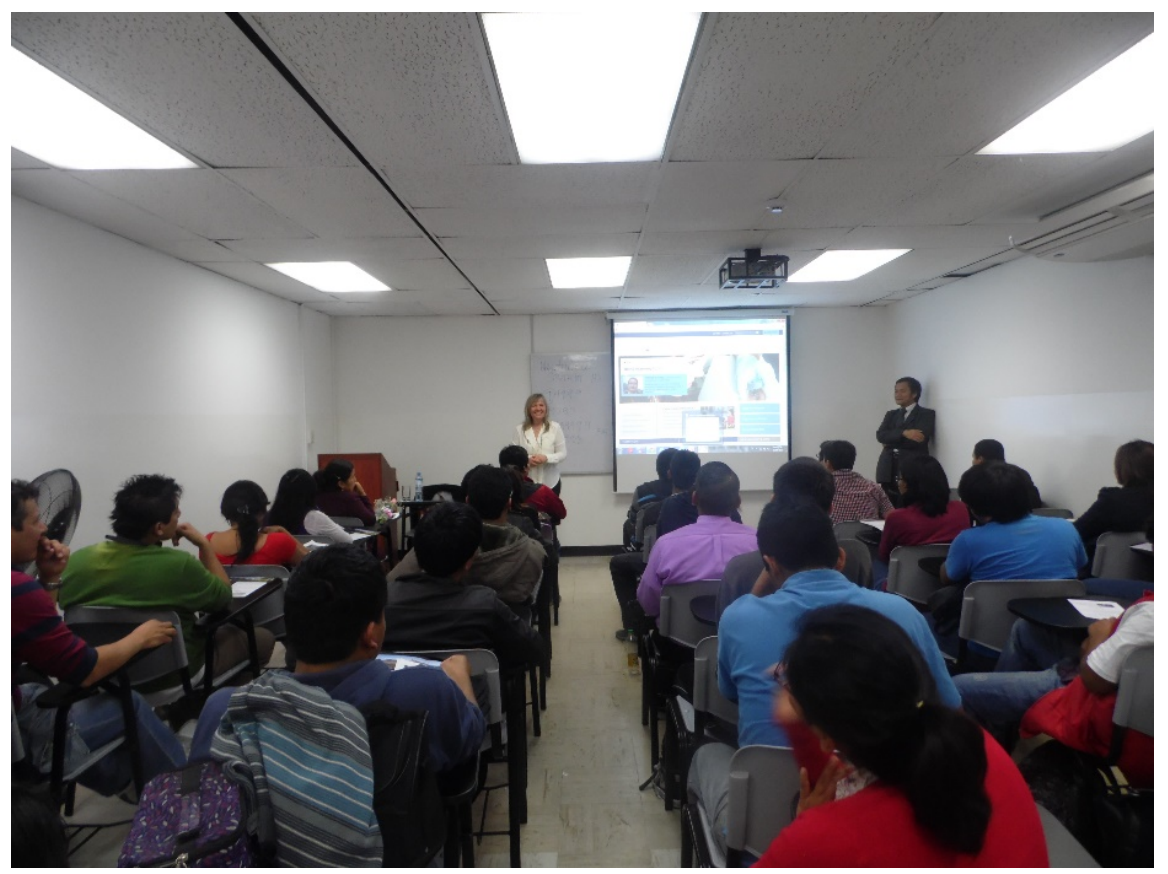

Figure 2. Professional from TRU giving conference in a classroom at UNW. Simultaneous translation is being done by professional from UNW. 


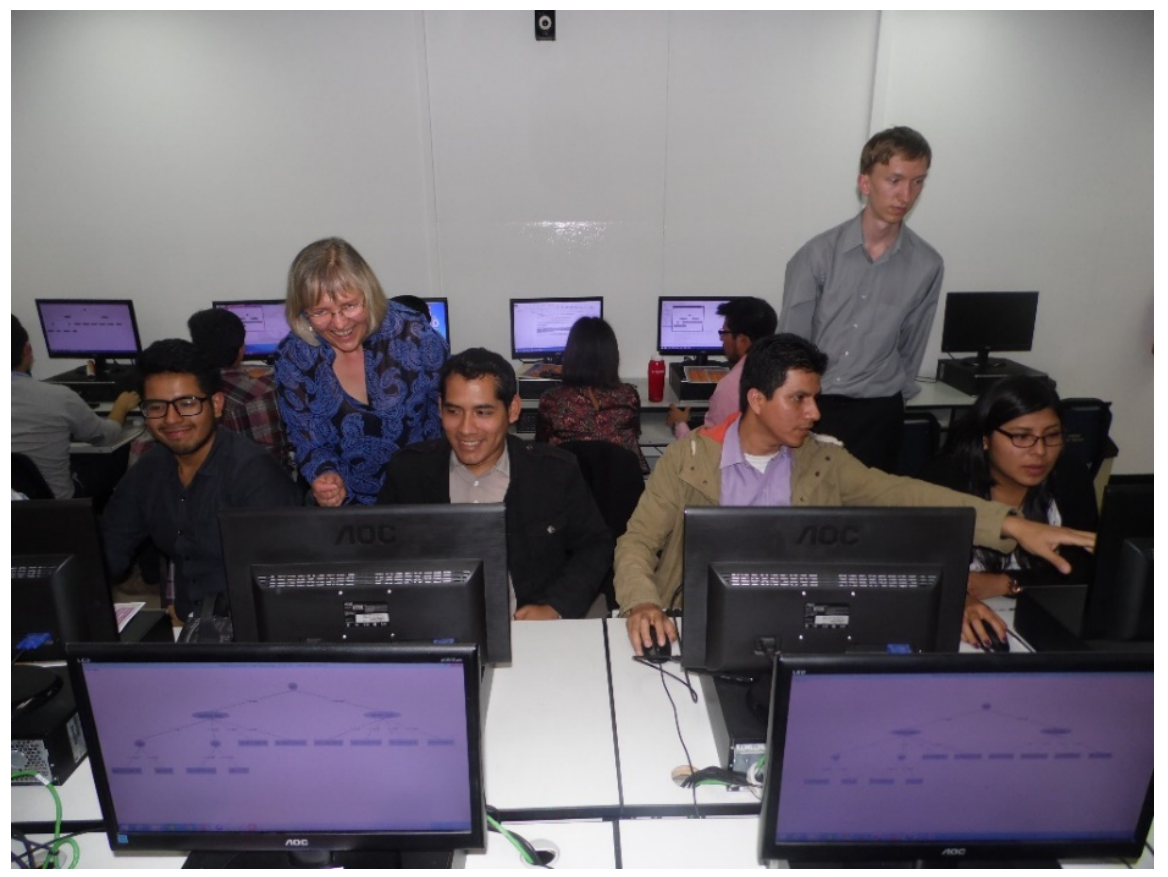

Figure 3. Professional from TRU giving workshop in a computer laboratory at UNW. Simultaneous translation is being done by professional from UNW.

related to the project cover aspects of: budget planning, resources allocation and course design.

d) ISO 9001 standards implemented at UNW. Universidad Norbert Wiener was founded by Dr. Alcibiades Horna Figueroa, in December 1996, with four careers: Pharmacy and biochemistry, Obstetric, Management, and Industrial Engineering. Dr. Horna searched for an institution that could verify quality in the execution of processes at the university. He thought of ISO standards, as a well-known standard worldwide. After a long training, formulation of processes, and adaptation to the norms, the University was certified with ISO standards in year 2000, for its four careers. Two new careers were created: Nursing in year 1999 and Systems and Informatics Engineering in 2001. Both careers moved toward ISO certification. In year 2003, these new careers certified for the first time, while the rest of the university recertified for version 2000 .

The procedure manual is based on Peruvian Technical Norm. A definition of ISO 9001 is presented, as well as a definition of an ISO manual.

WHAT IS ISO 9001? In a perspective from the academic point of view, ISO 9001 achieves continuous improvement. ISO tries to:

- Document processes, how a process should be done?

- Guarantee that processes are scheduled and performed on time

- Results of the process are measured and evaluated

- From the evaluation, continuous improvement is done

ISO MANUAL. This manual contains work instructions. A work instruction describes a process, based on guidelines. Identification of each work instruction is done by a code, with the advantage that the structure of the code contains in- 
formation about the classification of the work instruction. However, it was found that a sequential number was also useful, since it was shorter than a code. Currently, both identifications are used. ISO manual contains work instructions. For academic purposes, it includes:

- Management processes for careers

- Academic processes

- Support processes

Figure 4 shows the quality certification that UNW is allowed to use.

\subsection{Relational Capital}

Relational capital relates the Faculty of Engineering with the students; students' answer comes in the form of loyalty that UNW receives from the students, due to the conferences they constantly receive.

Communications: The first care is to avoid any cultural misunderstanding among the participants, and to break barriers that begin with the use of English as a foreign language. All the participants speak Spanish as native language, and have diverse levels of English as a foreign language; however all the lectures are given in English. The purpose is to help the participants have an experience in a technical matter, and also in English as a foreign language. This experience will be the base to build the relational capital.

\section{Achievements to Intellectual Capital}

Bilingual abilities are present in human capital and in relational capital. The use of English as a second language in Peru was fundamental for the communication between staff from Canada and Peru, and between Canadian lecturers and students.

The identification of tools in intellectual capital at the university is also an achievement for this project. The university is a place of research, social projection and cultural extension. The tools identified contribute to these functions. Figure 4 shows the quality certification for UNW.

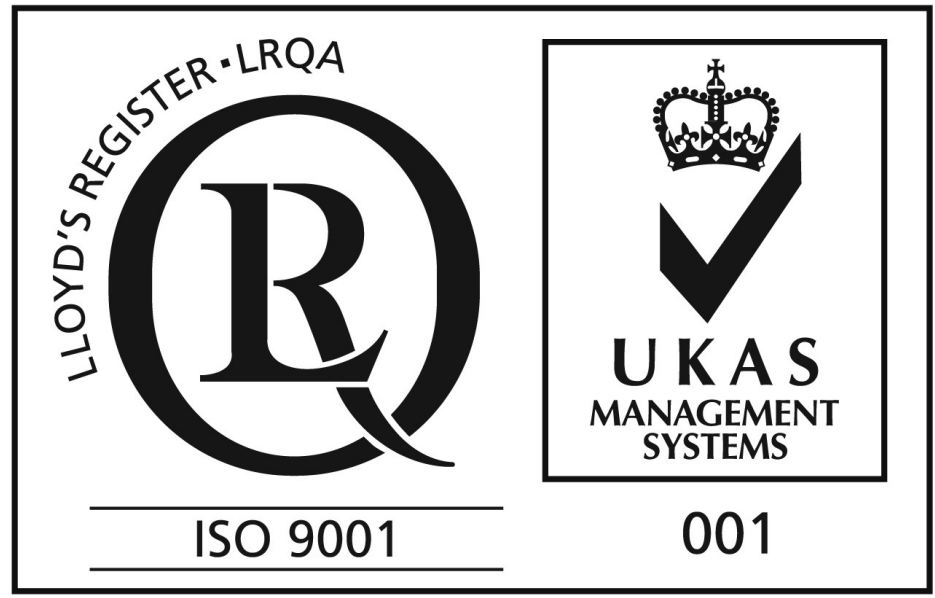

Figure 4. Quality certification for UNW. 
The tools are: Organizational structure, work instructions and ISO 9001 standards implemented at UNW.

Publishing two researches related to the project highlights and formalizes the use of intellectual capital concepts in this project.

\section{Discussion}

The professionals participating in a staff exchange that began in 2012 identified the opportunity to formalize the exchange for the next four years. The main academic theme was data mining for medical and health applications. However, the tool used to work on the project during four years was intellectual capital. The concept of intellectual capital was not the purpose of this project, but, along four years, intellectual capital arose as the most useful tool to manage the project. The components of intellectual capital existed at Universidad Norbert Wiener, and therefore it was feasible to bring the components together and build an intellectual capital tool.

\section{Conclusion}

Intellectual capital concepts have been applied to a bilingual project between Canada and Peru. The tools applied from intellectual capital made the project possible. As an answer to the research question, intellectual capital contributes to the success of the bilingual project between Canada and Peru, achieving human capital, using structural capital, and enhancing relational capital.

\section{References}

[1] Brătianu, C. and Pînzaru, F. (2015) Challenges for the University Intellectual Capital in the Knowledge Economy. Management Dynamics in the Knowledge Econo$m y$, 3, 609-627.

[2] Ramírez, Y., Tejad, Á. and Baidez, A. (2013) Intellectual Capital Report for Universities. World Academy of Science, Engineering and Technology. International Journal of Social, Behavioral, Educational, Economic, Business and Industrial Engineering, 7, 1423-1429.

[3] Griffith, M. (2017) Tapping into the Intellectual Capital at the University. $3^{\text {rd }}$ International Conference on Lifelong Education and Leadership for All ICLEL, Polytechnic Institute of Porto, Portugal, 12-14 September 2017.

[4] Cui, J., Huang, T., Cortese, C. and Pepper, M. (2015) Reflections on a Bilingual Peer Assisted Learning Program. International Journal of Educational Management, 29, 284-297. https://doi.org/10.1108/IJEM-12-2013-0175

[5] Kocoglu, I., Imamoglu, S. and Ince, H. (2009) The Relationship between Firm Intellectual Capital and the Competitive Advantage. Journal of Global Strategic Management, 3, 181-208. https://doi.org/10.20460/JGSM.2009318469

[6] Mhedhbi, I. (2013) Identifying the Relationship between Intellectual Capital and Value Creation of the Company Using Structural Equations Analysis-The Case of Tunisia. Journal of Business Studies Quarterly, 5, 216-236.

[7] Kwiatkowska, M. and Matthews, L. (2014) Analysis of Informational and Technological Requirements for Respiratory Therapy Workshops in Peru. 2014 IEEE Global 
Humanitarian Technology Conference (GHTC), San Jose, 10-13 October 2014, 675-681. https://doi.org/10.1109/GHTC.2014.6970355

[8] Kwiatkowska, M. and Un Jan, A. (2016) Teaching Bilingual Workshops on Data Mining in Peru. 2016 IEEE Global Humanitarian Technology Conference (GHTC), Seattle, 13-16 October 2016, 322-327. https://doi.org/10.1109/GHTC.2016.7857300

[9] Ley 30220 Ley de educación universitaria. Perú.

[10] Todericiu, R. and Serban, A. (2015) Economic Prospects in the Context of Growing Global and Regional Interdependencies. Procedia Economics and Finance, 27, 713-717. https://doi.org/10.1016/S2212-5671(15)01052-7

[11] Chen, C., Shih, H. and Yang, S. (2009) The Role of Intellectual Capital in Knowledge Transfer. IEEE Transactions on Engineering Management, 56. 402- 411. https://doi.org/10.1109/TEM.2009.2023086

[12] Ozcan, N., Cakan, S. and Kayacan, M. (2017) Intellectual Capital and Financial Performance: A Study of the Turkish Banking Sector. Borsa Istanbul Review, 17, 190-198. https://doi.org/10.1016/j.bir.2016.03.001

[13] Ciprian, G., Valentin, R., Grigore, V. and Aurelia, L. (2012) Elaboration of Accounting Financial Report on Structural Capital. Procedia-Social and Behavioral Sciences, 62, 706-710. https://doi.org/10.1016/j.sbspro.2012.09.119

[14] Khasawneh, S. (2011) Human Capital Planning in Higher Education Institutions: A Strategic Human Resource Development Initiative in Jordan. International Journal of Educational Management, 25, 534-544. https://doi.org/10.1108/09513541111159040

[15] Gogan, L., Rennung, F., Fistis, G. and Draghici, A. (2014) A Proposed Tool for Managing Intellectual Capital in Small and Medium Size Enterprises. Procedia Technology, 16, 728-736. https://doi.org/10.1016/j.protcy.2014.10.022

[16] Lenart-Gansiniec, R. (2016) Relational Capital and Open Innovation-In Search of Interdependencies. 19th International Conference Enterprise and Competitive Environment 2016, ECE 2016, Brno, March 2016, 10-11. https://doi.org/10.1016/j.sbspro.2016.05.495

[17] Tao, X. and Wang, W. (2013) Research on the Relationship between Intellectual Capital and Enterprise Performance: Perspective of Organizational Learning. International Conference on Education Technology and Management Science ICETMS 2013, Atlantis Press. https://doi.org/10.2991/icetms.2013.291

[18] Subramaniam, M. and Youndt, M. (2005) The Influence of Intellectual Capital on the Types of Innovative Capabilities. Academy of Management Journal, 48, 450-463. https://doi.org/10.5465/AMJ.2005.17407911 